\title{
Benchmark simulation models, quo vadis?
}

Jeppsson, U.; Alex, J; Batstone, D. J.; Benedetti, L; Comas, J.; Copp, J.B.; Corominas, L; Flores Alsina,
Xavier; Gernaey, Krist; Nopens, Ingmar Total number of authors:

17

Published in:

Water Science and Technology

Link to article, DOI:

10.2166/wst.2013.246

Publication date:

2013

Document Version

Publisher's PDF, also known as Version of record

Link back to DTU Orbit

Citation (APA):

Jeppsson, U., Alex, J., Batstone, D. J., Benedetti, L., Comas, J., Copp, J. B., Corominas, L., Flores Alsina, X., Gernaey, K., Nopens, I., Pons, M-N., Rodriguez-Roda, I., Rosen, C., Steyer, J-P., Vanrolleghem, P. A., Volcke, E. I. P., \& Vrecko, D. (2013). Benchmark simulation models, quo vadis? Water Science and Technology, 68(1), 1-15. https://doi.org/10.2166/wst.2013.246

\section{General rights}

Copyright and moral rights for the publications made accessible in the public portal are retained by the authors and/or other copyright owners and it is a condition of accessing publications that users recognise and abide by the legal requirements associated with these rights.

- Users may download and print one copy of any publication from the public portal for the purpose of private study or research.

- You may not further distribute the material or use it for any profit-making activity or commercial gain

- You may freely distribute the URL identifying the publication in the public portal 


\title{
Benchmark simulation models, quo vadis?
}

\author{
U. Jeppsson, J. Alex, D. J. Batstone, L. Benedetti, J. Comas, J. B. Copp, \\ L. Corominas, X. Flores-Alsina, K. V. Gernaey, I. Nopens, M.-N. Pons, \\ I. Rodríguez-Roda, C. Rosen, J.-P. Steyer, P. A. Vanrolleghem, \\ E. I. P. Volcke and D. Vrecko
}

\section{ABSTRACT}

As the work of the IWA Task Group on Benchmarking of Control Strategies for wastewater treatment plants (WWTPS) is coming to an end, it is essential to disseminate the knowledge gained. For this reason, all authors of the IWA Scientific and Technical Report on benchmarking have come together to provide their insights, highlighting areas where knowledge may still be deficient and where new opportunities are emerging, and to propose potential avenues for future development and application of the general benchmarking framework and its associated tools. The paper focuses on the topics of temporal and spatial extension, process modifications within the WWTP, the realism of models, control strategy extensions and the potential for new evaluation tools within the existing benchmark system. We find that there are major opportunities for application within all of these areas, either from existing work already being done within the context of the benchmarking simulation models (BSMs) or applicable work in the wider literature. Of key importance is increasing capability, usability and transparency of the BSM package while avoiding unnecessary complexity. Key words | benchmarking (BSM), control, evaluation, modelling, process monitoring, wastewater treatment
U. Jeppsson (corresponding author) $\mathrm{X}$. Flores-Alsina

Div. of Industrial Electrical Engineering and

Automation (IEA), Lund University, Box 118, SE-221 00 Lund, Sweden

E-mail: ulf.jeppsson@iea.Ith.se

J. Alex

ifak e.V. Magdeburg, Werner-Heisenberg-Str. 1, D-39106 Magdeburg, Germany

D. J. Batstone

AWMC, Advanced Wastewater Management Centre, University of Queensland, Brisbane, QLD 4072, Australia

L. Benedetti

WATERWAYS srl, Via del Ferrone 88,

50023 Impruneta (FI), Italy

J. Comas

I. Rodríguez-Roda

Laboratory of Chemical and Environmental Engineering, University of Girona, Campus Montilivi s/n, 17071 Girona, Catalonia, Spain

J. B. Copp

Primodal, Inc., 122 Leland Street, Hamilton

Ontario L8S 3A4, Canada

L. Corominas

I. Rodríguez-Roda

ICRA (Catalan Institute for Water Research)

Scientific and Technological Park of the University of Girona, $\mathrm{H} 2 \mathrm{O}$ Building,

Emili Grahit 101, 17003 Girona, Spain

X. Flores-Alsina

K. V. Gernaey

Dept. of Chemical and Biochemical Engineering Technical University of Denmark, Building 229,

DK-2800 Kgs. Lyngby, Denmark

I. Nopens

BIOMATH, Ghent University,

Coupure Links 653, B-9000 Ghent, Belgium

M.-N. Pons

LRGP-CNRS, Nancy University,

INPL, 1 rue Grandville, BP 451,

F-54001 Nancy cedex, France

C. Rosen

Veolia Water - Solutions \& Technology, AnoxKaldnes $A B$, Klosterängsvägen $11 \mathrm{~A}$

SE-226 47 Lund, Sweden

J.-P. Steyer

INRA, UR050,

Laboratoire de Biotechnologie de l'Environnement, Avenue des Etangs, Narbonne, F-11100, France

P. A. Vanrolleghem

modelEAU, Dépt de génie civil et de génie des

eaux, Université Laval, Québec, G1V 0A6, QC, Canada 


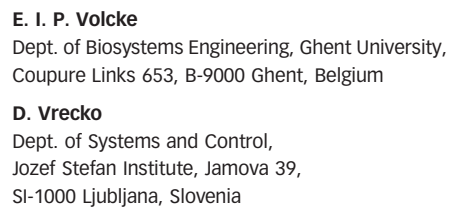

\section{INTRODUCTION}

Over the past decade, considerable investments have been made in acquiring knowledge as to how to best perform objective benchmarking of control and monitoring strategies for wastewater treatment plants (WWTPs) and how to evaluate the results using a detailed simulation protocol. Comparisons focus on the relative differences of implemented control and monitoring strategies, rather than the absolute output values, as the inherent uncertainties of many WWT process models may still be a problem for some practical applications. However, the success of the COST/IWA benchmark simulation models BSM1, BSM1_LT and BSM2 (e.g. Spanjers et al. 1998; Copp 2002; Rosen et al. 2004; Jeppsson et al. 2007; Nopens et al. 2010; Corominas et al. 20II; Gernaey et al. 20I3; http://www.benchmarkwwpt.org) for control strategy and monitoring system development and evaluation clearly illustrates the usefulness of such tools for the wastewater research community. More than 300 papers, conference presentations and theses on work related to the benchmark systems have been published to date. The freely available simulation models are used by numerous research groups around the world for various purposes and are available as predefined software tools in several commercial WWTP simulator packages (e.g. GPS$\mathrm{X}^{\mathrm{TM}}$, SIMBA $\left.^{\circledR}, \mathrm{WEST}^{\circledR}\right)$ - as well as in a stand-alone FORTRAN implementation and for the general MATLAB ${ }^{\circledR} /$ SIMULINK $^{\circledR}$ platform. Implementations (and ring-testing) with varying success have also been achieved in STOAT ${ }^{\mathrm{TM}}$, BioWin $^{\mathrm{TM}}$, AQUASIM, JASS, SciLab, EFOR ${ }^{\mathrm{TM}}$ and LabVIEW.

Efforts have focused on providing tools for analysing and solving real problems for real WWTPs and establishing a general platform and simulation protocol that can be further extended in the future. As the IWA Task Group on Benchmarking of Control Strategies prepares to publish the official scientific and technical report (STR) in 2013 (Gernaey et al. 20I3), it is important to take advantage of the experience gained by the researchers that have been involved in the BSM development over the years. This paper has been written to define potential avenues for future work, as well as to suggest potential uses for the
BSM platform and its associated tools. For this purpose, all authors of the BSM STR have come together in this paper to highlight areas where knowledge may still be deficient and where new opportunities are emerging for future BSM development and application. Hopefully, the paper may also serve as a guide for current and future development and use of simulation tools for wastewater treatment systems in general.

Although valuable tools, the current BSM systems do not include all aspects of importance for benchmarking WWTP control and monitoring strategies. A number of potential pathways for extensions have been identified and are discussed in this paper. These include: (1) temporal extension; (2) spatial extension; (3) process extensions within the WWTP; (4) realism of the models used in the BSM; (5) control strategies extension; and (6) extended evaluation tools.

\section{$\overline{\text { TEMPORAL EXTENSION }}$}

In BSM1, only 14-day influent data series for dry, rain and storm conditions were necessary. These data series were generated from a real data set combined with some hypotheses on correlated influent characteristics (Spanjers et al. I998). This was sufficient for BSM1, but insufficient for long-term simulations as desired for BSM1_LT and BSM2 (1-2 years). To deal with longer term simulations, a phenomenological influent wastewater generator model was developed (Gernaey et al. 20II) to provide realistic influent data to the BSMs. Should the objective of future BSMs become more ambitious, it might require even longer influent data files to perform complete scenario analyses. For example, one might want to include the impact that climate change will have on the precipitation regimes (e.g. extreme rainfall events or drought periods), air/water temperature or snow melting periods (Semadeni-Davies 2004; Semadeni-Davies et al. 2008; Plósz et al. 2009). These factors will strongly impact the quantity and quality of the influent wastewater as well as the way future WWTPs might be 
operated. Another possible example requiring temporal extension could be changes in the urban catchments. This might include changing from combined to separated systems or even to source treatment, separate storm water treatment, use of rainwater for non-potable water use, longer sewer networks or the appearance/increase/decrease of new pollutants (Ashley et al. 2007). All such changes take place over a long time scale and the evaluation period may therefore need to be extended to 10 or even 50 years to include the capability for this sort of evaluation. Due to ever-increasing computational power, it is today possible to extend the evaluation period of BSM to 5 or 10 years and still include all the detailed effects when performing simulation-based scenario analysis. For longer simulation periods parts of the simulation model can be speeded up (e.g. Ráduly et al. 2007). However, the practical relevance of results based on such extended simulations can be argued, as the necessary system assumptions made would often be highly uncertain, partly because of the difficulty of capturing all relevant changes that will certainly occur in the way of life of inhabitants within a 50-year period. Other long-term phenomena that should be considered, but do not currently fit into the input file, are issues like fouling of the aeration system with consequent efficiency decrease, and events which may occur sporadically but have a significant impact like maintenance line closures and equipment failures (Rosso \& Stenstrom 2006). Such modifications would require the consideration of some practical modelling and simulation aspects including simulation speed and model accuracy. Development in this direction can be found in Benedetti (2006).

\section{SPATIAL EXTENSION}

The family of benchmark systems are defined as "within-thefence' systems, i.e. the model descriptions and simulations do not extend outside the borders of the WWTP. The importance of the sewer system and processes in the receiving waters was recognised by the Task Group but including these complicating factors in the original BSMs were deemed to be beyond the Task Group's scope. However, this is a topic of the EU FP7 project called SANITAS (www.sanitas-itn.eu).

\section{Sewer network}

From a control and monitoring perspective the inclusion of the sewer network into the benchmark system would open up a range of new possibilities for interactions and manipulation of the combined sewer/WWTP system (e.g. back-flow effects, storm tanks and pumping stations, combined sewer overflows (CSOs), pollution contributions from run-off). For example, the KOSIM sewer model (ITWH 2000), which was designed to calculate pollutant loads to the WWTP and the receiving waters in the context of planning and dimensioning of sewer systems and storage tanks, has already been used in an integrated context (Solvi et al. 2006). The KOSIM model does not include biochemical reactions and transformations, but several models similar to the activated sludge model (ASM) are available to describe the chemical and microbial transformations of organic matter, nitrogen and sulphur within the sewer (e.g. Hvitved-Jacobsen et al. I998; Sharma et al. 2008; Guissassola et al. 2009; Jiang et al. 20Io). A few examples already exist where ASM-like sewer models have been integrated with the BSM platform for integrated urban wastewater system (UWWS) simulations (e.g. Sharma et al. 20I2).

\section{Receiving waters}

As for receiving waters, existing models such as the River Water Quality Model No. 1 (Reichert et al. 20oI) or simplifications thereof (Schütze et al. 20II), can be added or linked to the BSMs without too much difficulty, given the proper interfaces (Benedetti et al. 2007). This kind of approach would be particularly beneficial for more detailed evaluation of the environmental impact of wastewater pollutants. As well, this combination would promote the use of the benchmark system as a decision support tool in agreement with current river basin management approaches, as pursued by the EU Water Framework Directive (EC 2000) (i.e. immission-based rather than emission-based). Integrated evaluation experience can already be found in Benedetti et al. (2010) and Brehmer et al. (2009). As with all other benchmarking tools developed so far, consensus will have to be reached on objective evaluation criteria that assess the urban water quality impacts in receiving waters, but ideas for this are not lacking (e.g. Bauwens et al. 1996; Benedetti et al. 20Io).

\section{PROCESS EXTENSIONS WITHIN THE WWTP}

The original purpose of the benchmark system was to allow for the objective comparison of control and monitoring strategies of a treatment plant removing organic carbon and nitrogen, and therefore a fixed plant layout was defined 
and used. In many cases, however, users have experienced a need to modify the layout (plant configuration) or have added additional treatment process models, thereby creating a WWTP more suited for their specific application, e.g. to benchmark potential plant upgrades (see for example the EU-CD4WC project, Benedetti et al. (20I0)) while maintaining the original set of benchmark performance evaluation criteria. Specifically for nitrogen removal, process models of an oxidation ditch plant configuration (Abusam et al. 2002), the combined SHARON-Anammox (anaerobic ammonium oxidation) process (Dapena-Mora et al. 2004), membrane bioreactors (Maere et al. 20II) and many more have been added to the BSM platform. Extensions of the plant configuration towards bio-P removal have been reported as well (Gernaey \& Jørgensen 2004).

In many cases these add-ons have been defined and implemented without any insight from the Task Group and have remained the property of the individual research groups. This contrasts with the Task Group philosophy, which has always aimed to freely distribute verified implementations of the benchmark plants. The global research community would certainly benefit if those additional models could be collected, standardised, verified and then made generally available as an extended BSM model library. One option for a formalised model library, at least for ASM-type models, was suggested in Alex et al. (2005) using an XML (extensible markup language) format description. Indeed, for many potential benchmark users, the amount of work involved in developing their own process extensions is an important factor when considering whether or not to use one of the existing benchmark plants for a specific situation or plant.

It is clear from the above that process extensions within the WWTP are related to the appearance of models for new unit processes, such as the SHARON and the Anammox processes (Volcke et al. 2006a). We expect that this evolution will continue in the future. At this moment, additional process extensions related to integrated fixedfilm processes (Vanhooren et al. 2002) and sludge blanket reactor (SBR) configurations are needed to address current requirements. One issue that is often forgotten is that process extensions coincide with the need for suitable model interfaces when the state variables in the model of a new unit process are different from the state variables in the original benchmark models. The function of these interfaces is to ensure that material mass balances and continuity principles are met, and ensures the proper mapping of the output variables of one model to the most appropriate input variables of another model (Alex et al.
2005; Vanrolleghem et al. 2005b; Volcke et al. 2006b; Nopens et al. 2009).

\section{REALISM OF THE MODELS USED IN THE BSMS}

The process extensions outlined above rely on the availability of models for new unit processes. However, it is also recognised by the authors that the models currently used in the BSMs might undergo changes in the future. Indeed, the mathematical models used in the BSMs today were chosen because they were internationally accepted and well-established, such as ASM1 (Henze et al. 1987), a 10-layer one-dimensional (1-D) settler model (Takács et al. I99I) and ADM1 (Anaerobic Digestion Model No. 1) (Batstone et al. 2002). There is, however, an almost unlimited possibility to extend and upgrade the models within the existing BSM plant configurations, including the models describing sensors and actuators (e.g. more detailed and dynamic models of blowers and pumps). Obviously the aim of any changes would be to enhance realism of the systems rather than to simply increase the level of detail and complexity. In some cases, improved models have become available since development of BSM1 and BSM2 was initiated. Although the Task Group decided not to change models during development, most of these updated models are well described, and thus can be (easily) interchanged in the current BSM framework. Furthermore, the BSM framework can be used to test models under development. An overview of possible model extensions and future inclusions is listed below.

\section{ASM2d (phosphorus removal)}

The advantage of including ASM2d is that phosphorus (P) removal (both biochemical and chemical) is added to the BSM framework. This would allow for the inclusion of $\mathrm{P}$ limits to the effluent quality index (EQI) and chemical dosing for P-precipitation to the operational cost index (OCI) (see later section for discussion of EQI and OCI). These inclusions would then force P-related 'costs' to be accounted for when developing general control strategies or allow for the benefits to be quantified if specific strategies for P-removal were being investigated. Given the fact that low effluent P-limits are common, this extension would be timely. It should, however, be noted that the addition of $\mathrm{P}$ would require also an update to ADM1 (see below) for P-related components and processes (Harding et al. 20II). Furthermore, ASM2d does not come with realistic default parameters (Henze et al. 2000; Hauduc et al. 20II). Last 
but not least, the fact that decay rates are not electron acceptor dependent in ASM2d might lead to an overestimation of the decay rate in the system. ASM2d can be modified to account for electron acceptor dependent decay rates (Gernaey \& Jørgensen 2004; Benedetti et al. 20Io; Flores-Alsina et al. 2012), as evidenced by the successful application at full-scale plants as well (Ingildsen et al. 2006).

\section{ASM3}

ASM3 introduces the concept of storage and applies the endogenous respiration concept to describe the decrease of biomass and storage products over time. Some argue that this is a better approach in certain instances than the approach used in ASM1. However, again, a drawback is the high number of parameters for which no verified default set is defined (Henze et al. 2000; Hauduc et al. 20II).

\section{Multi-step nitrification/denitrification and $\mathrm{N}_{2} \mathrm{O}$ production}

The current BSM relies on single-step nitrification and singlestep denitrification, which is based on the assumption that nitrite does not accumulate in typical WWTPs. However, nitrite is known to accumulate during unstable operation, at high temperatures, within side-stream processes and in industrial WWTPs (Sin et al. 2008). Low oxygen levels applied to WWTPs in view of energy savings also increase the chance of nitrite accumulation. The need to include nitrite in the future will result from the need to better estimate the exact effluent nitrogen load. Also novel nitrogen removal principles based on nitritation and nitritation-denitritation processes will require a substantially increased level of detail for modelling the transformation of nitrogen components (Gustafsson 20II). In addition, $\mathrm{N}_{2} \mathrm{O}$ production in WWTPs currently receives considerable attention because of its greenhouse gas (GHG) potential. Kampschreur et al. (2009) found that both the nitrification and denitrification stages contribute to the production of $\mathrm{N}_{2} \mathrm{O}$ under certain specific conditions, such as low oxygen concentrations, increased nitrite concentrations and low ratios of chemical oxygen demand (COD) to nitrogen in the denitrification stage. If the BSM performance criteria are extended to GHGs then $\mathrm{N}_{2} \mathrm{O}$ will have to be modelled in detail (e.g. Hiatt \& Grady 2008; Mampaey et al. (in press); Ni et al. 20II; Ni et al. 20I3). Multi-step nitrification/denitrification models including $\mathrm{N}_{2} \mathrm{O}$ production have already been implemented in a benchmark framework (Flores-Alsina et al. 20II; Corominas et al. 2012; Guo et al. 2012; Snip et al. 20I3). Studying this in more detail is one of the tasks defined in an
IWA task group focusing on 'The use of water quality and process models for minimising wastewater utility greenhouse gas footprints' (see http://www.iwataskgroupghg.com/).

\section{Sulphur reducing/oxidising reactions}

Sulphate is a key electron sink in anaerobic systems. Sulphate will reduce to sulphide under anaerobic conditions and will progressively re-oxidise to poly-sulphide, sulphur and sulphate under aerobic conditions. Its direct impacts are numerous and include a reduction in methane flow (due to the loss of electrons), inhibition of anaerobic microbes and sulphide contamination of the gas phase (Fedorovich et al. 2003). Levels in domestic sewage are normally very low $(<10 \mathrm{ppm})$ though nonetheless resulting in gas-phase sulphide concentrations in the order of $1,000 \mathrm{ppm}$; this is enough to decrease the value of the gas produced and should be included in the models eventually. Sulphate also has a subtle impact on the phosphorus system. In the presence of sulphide, iron phosphate resolubilises in anaerobic digesters (Ge et al. 20I3). Making the task of incorporating sulphur into the BSM structure easier is one of the objectives for the future since there are various published models available to describe sulphate reduction (e.g. Fedorovich et al. 2003; Poinapen \& Ekama 2010).

\section{Thickener and dewatering models}

To date, ideal models have been used for these units in the BSMs. The implemented models are based on steady-state mass balances for specific thickening/dewatering efficiencies and given amounts of suspended solids in the sludge streams (Jeppsson et al. 2007). However, because these processes are dynamic in reality and can impact the sludge balance of the system, they can affect the biodegradation rates in the activated sludge reactors, the gas production and composition from the anaerobic digester, as well as the amount of sludge stored in the secondary clarifier. Such BSM outputs are embedded in the evaluation criteria and can potentially impact development of control strategies. More complete models could be developed and included.

\section{Settler models}

The most widespread model used in simulations of activated sludge plant systems is the Takács 1-D multi-layer clarification-thickening dynamic model (Takács et al. I99I). Nevertheless, many researchers have pointed out the poor relationship between the model parameters and the 
physicochemical properties of the sludge flocs (viscosity, density...) (e.g. Kinnear 2002). Alternative models exist and could easily be integrated with the existing BSMs. During the last years, several researchers have been working on improving the mathematical models describing total suspended solids (TSS) separation in clarifiers using more elaborate formulations (e.g. Diehl 2008; Bürger et al. 20II). Watts et al. (1996) stressed the importance of adding the effect of dispersion to gravity and upwards/downwards convective bulk movement in the overall TSS balance. Plósz et al. (20II) further improved the previous model formulation considering the impacts related to the horizontal density currents in the downwards convective bulk movement by adding a reduction factor. Simulation results showed better assessment of the clarifier storage capacity and the sludge concentration in the effluent stream. In the field of batch settling, the work carried out by De Clercq et al. (2008) must be mentioned, where a mechanistic model based on Kynch's batch density functions and solids stress functions was calibrated for different types of sludges. Finally, Jeppsson \& Diehl (1996) pointed out the special attention that must be paid to numerics in order to produce reliable simulation results.

\section{Reactive settler processes}

The current BSMs have biologically inactive primary and secondary settler models included. In the case of a long residence time in the primary settler, a portion of the influent hydrolysis will not be accounted for, which could impact the behaviour of the activated sludge reactors and, hence, all controllers developed based on that. Reactive primary and secondary settler models have been proposed before and validated using full-scale data (Keller \& Yuan 2002) and also linked to ASM models in the BSM platform (Gernaey et al. 200I, 2006; Flores-Alsina et al. 2012). An important reaction in the secondary settler when residence times increase is the occurrence of denitrification. This phenomenon has important implications in P-removal systems since the quantity of returning nitrates to the anaerobic section via external recirculation might be overestimated (Flores-Alsina et al. 2012). Secondary settler denitrification may also hamper the settling process. This was partially anticipated by defining a risk index for settling in the BSMs (Comas et al. 2008). However, a general problem with ASM1-based reactive settler models is the overestimation of decay, as decay simply continues in the settler no matter the electron acceptor present (Gernaey et al. 2006; Flores-Alsina et al. 2012).

\section{Time-varying parameters regarding settling, foaming and biodegradation}

To date, BSM models have used default parameter sets, which were taken from the original references. However, in practice, system behaviour can be different and these parameter values might be varying as a function of time. This is quite commonly known for settling but models describing the direct link between sludge settleability and settling behaviour are not yet available. Work on a fuzzy rule-based system to infer the risk of settling problems is ongoing (Comas et al. 2008). Simulation of poor or good settling characteristics can be established by modifying the model parameters online based on the estimated risk of settling problems (FloresAlsina et al. 2009). Knowledge-based models can also be designed to provide as output the risk of foaming in anaerobic digesters (Dalmau et al. 20Io). With respect to biodegradation, current ASM models contain temperature for process kinetics. One could easily imagine other impacts to include, e.g. inhibition. This can be accomplished by modifying the typical Monod expressions with a wide range of possible inhibition functions (Rosen et al. 2008a).

\section{Degradation processes for micro-pollutants}

New regulations stress the importance of estimating the loads and the fate of micro-pollutants (MPs) in the water cycle. The models available to simulate the transport and removal of 'traditional' pollutants, such as organic matter, nutrients and suspended solids in WWTPs can be extended with processes describing the fate of MPs (i.e. physical, chemical and biological processes) (e.g. Lindblom et al. 2006; Schönerklee et al. 2009; Benedetti et al. 2009a; Barret et al. 2010; Plósz et al. 20Iо; Delgadillo et al. 20II). The fate models may be used to determine the distribution of the regulated MPs between solid, liquid and gas phases, so that monitoring of the contaminants can be done more efficiently (De Keyser et al. 2010). Should regulatory limits be imposed with maximum or 'never to exceed' effluent concentrations or loadings, dynamic modelling is required to determine under what set of operating conditions compliance with the limits would be maintained (or alternatively under which conditions effluent limits might be exceeded, and for how long).

\section{Soluble microbial products}

ASMs do not describe the mechanism of soluble microbial product (SMP) formation and degradation during substrate 
metabolism and endogenous respiration processes, which are divided into utilisation-associated products and biomass-associated products (Rittmann et al. 1987; Barker \& Stuckey 1999). Traditional models of WWT systems, including the BSMs, predict that the effluent concentration of soluble biodegradable organic matter is independent of the influent biodegradable substrate concentration, but this does not agree with observations, which show that an increasing influent biodegradable COD concentration will lead to an increasing effluent soluble COD concentration. The incorporation of SMP formation and degradation thus allows for more accurate modelling of WWT processes (Barker \& Stuckey 1999; Aquino \& Stuckey 2002; Lu et al. 2002; Fan et al. 2012) and membrane bioreactors in particular where they play a role in membrane fouling (OliveiraEsquerre et al. 2006; Jiang et al. 2008).

\section{Physicochemical processes}

Physicochemical processes occurring in wastewater treatment indirectly affect the biological conversions taking place. The descriptions in popular models, such as the ASM1, are limited to essential elements only, so $\mathrm{pH}$ for example is not described using the existing models. The ASM1 uses a global alkalinity state, but alkalinity does not properly consider the continuum that exists when there are both weak and strong acids present. The ADM1, however, includes $\mathrm{pH}$ calculation. The fact that $\mathrm{pH}$ is described in some but not all BSM sub-models requires particular attention during model coupling (Volcke et al. 2006b; Nopens et al. 2009) and provides a strong argument to develop a common physicochemical model across the whole system (Grau et al. 2007). The effect of non-ideal behaviour (i.e. activity, ion pairing, etc.) needs to be included for concentrated wastewater streams. Precipitation is also highly important and currently not included in the BSMs. ASM2d considers empirical relationships for precipitation or re-dissolution of metal phosphate complexes. ADM1 does not consider metal precipitation, although a potential approach is provided by Batstone et al. (2002). Jones et al. (2007) have presented a physicochemical model that is valid for the whole WWTP. Recently, an IWA task group working on physicochemical aspects in biological (waste) water treatment modelling has been established. This group (see www.iwahq.org/Home/Networks/Task_groups/ Task_Group_on_Physicochemical_Framework) is addressing various physicochemical aspects besides the abovementioned acid-base and precipitation reactions (Batstone et al. 20I2) and is working towards a generalised physicochemical model widely applicable to water and wastewater. Once established, such a generalised physicochemical model can then also be applied to the BSM platform. The commonality of physicochemical processes across the whole of the WWTP and difficulty in interfacing different physicochemical models (Nopens et al. 2009) argues for the application of the same physicochemical model in all subprocesses.

Work has been initiated for about half of the above topics during the last few years, using the BSM platform. The added realism to simulation results through such model extensions will also promote the use of the benchmarking framework for more practical applications, on the conditions that the new models are properly verified, calibrated and validated. Availability of a considerable number of new or extended models will potentially mean that the distribution of the BSMs will have to be reconsidered, for example by making a general library of ringtested unit process models available instead of models of pre-defined full-plant configurations.

\section{CONTROL STRATEGIES EXTENSION}

The advances in instrumentation and automation allow us to have access to information regarding the UWWS in real-time and at high levels of accuracy. Not only can this information be acquired from the WWTP, but also on-line sensors can be installed in the sewer systems, and monitoring stations are being developed for monitoring river water quality. In this sense, large quantities of data are now becoming available and can be used for fault-tolerant, uncertainty-aware and system-wide control design (Olsson et al. 2005; Olsson 20I2).

\section{Fault-tolerant control}

The use of on-line sensors in control and automation for optimised operation of WWTPs is common practice. However, it is necessary to use methods to check the quality of the signals provided by these sensors because they are subject to failures (drift, shift, calibration, etc.) (Rieger et al. 2003; Rosen et al. 2008b). Poor signal quality can lead to undesired control actions causing severe effluent limit violations or increase of operating costs (Steyer et al. 2006). In view of control implementation in full scale it is necessary to develop new tools and new strategies to increase the reliability. Therefore, fault detection methods and fault diagnosis (to identify the root cause of the fault) should be coupled to control methods 
to assure fault-tolerant control (Alcaraz-Gonzalez et al. 2005; Mhaskar 2006; Zumoffen \& Basualdo 2008; Corominas et al. 20II). The benchmark platform can be used to demonstrate the validity of such control systems and allow for the evaluation of the effects of faults in active controllers and the resulting overall plant performance.

\section{Uncertainty-aware control}

Proper control of wastewater treatment systems strongly depends on reliable input information, which is usually obtained from fast and simple measurements (e.g. dissolved oxygen, nitrates, ammonium, biogas flow rate, biogas composition, $\mathrm{pH}$ ) or estimated from mathematical structures called observers. Several identification techniques can be used for the design of state observers. Kalman Filtering represents a rigorous and powerful methodology that has been applied for on-line state estimation in WWTPs (e.g. Beck I98I; Bernard et al. 2006). Nevertheless, there are other observer and estimation techniques that can be beneficial for wastewater treatment (e.g. Alcaraz-Gonzalez et al. 2002; Lardon et al. 2004). Hence, in a similar way as is done for monitoring methods, the BSM platform could be used to evaluate and compare different types of estimation methods.

\section{System-wide control}

System-wide control can be used to manage the UWWS as one integrated unit. The conventional approach is to design and operate each system component separately, e.g. sewer system, storm tanks, WWTP, receiving water bodies. However, it is unlikely that the optimal performance of the UWWS will be realised using such an approach. The system-wide concept was described by Beck (1976) and can now be applied because of the improvement of monitoring systems, mathematical models and increased computational power. Butler \& Schütze (2005) demonstrated that the application of conventional criteria (e.g. overflow volumes, discharged pollutant loads) can result in misleading conclusions when assessing the performance of the UWWS under various scenarios, and therefore immission-based approaches are required (Benedetti 2006). However, system-wide control is a difficult task because of the interactions between the different elements of the system (Rauch et al. 2002) and requires the development of new tools that provide information about scenario analyses and operational procedures, which improve the performance of the overall UWWS. Efforts towards this objective have already been initiated by the sewer system research community: realistic virtual sewer systems are created (now even automatically, Sitzenfrei et al. (20I0)) and control strategies are objectively compared within a benchmarking context (e.g. Borsanyi et al. 2008). From an integrated perspective, control actions taken within a combined sewer system can reduce CSOs and increase the load to the WWTP, at the expense, perhaps, of the WWTP's performance (Bauwens et al. I996; Rauch \& Harremoës 1999; Schütze et al. I999; Vanrolleghem et al. 2005a; Benedetti et al. 2009b). This is still not a fully accepted approach and lacks widespread application in practice. Its future use may increase if the approach were incorporated into the existing BSM initiative and more widely promoted in the associated research community. The available BSM methodology may be adapted for combined sewer system control, and system-wide control approaches could be investigated by integrating the sewer system, WWTP and the receiving waters into one extended benchmark system.

\section{EXTENDED EVALUATION TOOLS}

The basic premise on which benchmarking is based is the metrics used in the evaluation phase. The availability and reliability of the evaluation tools to effectively 'score' the process under study are essential for the success of any benchmark system. Hence, the evaluation criteria (the metrics) must efficiently simplify a complex comparison into a few meaningful index values that capture the relative strengths and weaknesses of the items being compared. The approach adopted during the BSM development was to develop criteria that were independent of location so that the BSM application was not constrained by jurisdiction. Use of the current BSM criteria and recent advances in research knowledge have highlighted some deficiencies in the current evaluation criteria. Nevertheless, the vision for extending the evaluation criteria follows this basic approach, namely, that the criteria should be as much as possible independent of jurisdiction.

The current BSM platform is based on three main types of evaluation criteria (effluent quality, operational cost issues and risk). Effluent quality is considered through an EQI, which has been defined to quantify into a single term the effluent pollution load to a receiving water body. This combined with an effluent violation metric gives a reasonable overview of the ability of the benchmarked system to meet a particular effluent requirement whatever that might be. Energy 'costs' are considered through pumping, mixing and aeration 
energy calculations. Sludge 'costs' are considered through sludge production and disposal calculations, and costs related to chemical additions are also included (external carbon source). Together these 'costs' form an OCI using empirical factors. Finally, process risk is considered through a fuzzy logic calculation of microbiology-related operational problems to create a risk index. Each of these will remain a part of the protocol, although further validation and extension of the cost and risk indices need to be performed.

\section{Energy consumption models}

In particular, energy consumption and production (and the associated costs) should be modelled in more detail. Energy efficiency (and even self-sufficiency) is an important decision driver in a modern day WWTP (Siegrist et al. 2008). Strategies that show improved process efficiency will be considered at full scale, but only if the model used to calculate those efficiencies is sufficiently accurate (Rosso \& Stenstrom 2006). For example, new digestion processes which show promise in solids destruction and energy production are coming on-line at full scale. As the BSM framework will be expanded to new plant layouts, such as SBRs, oxidation ditches or membrane bioreactors, the evaluation criteria will have to be adapted to these new configurations. To keep pace, the BSM evaluation criteria will have to be expanded and validated to ensure that these criteria accurately predict the relative change in energy consumption and production.

\section{Microbiology-related TSS separation problems}

Process risk is defined within the BSM context as the risk of failure due to settling problems of microbiological origin, such as the proliferation of foaming and bulking organisms. The risk index is calculated based on a fuzzy logic approach using model-based process variables (Comas et al. 2008). This index is a promising development with the potential to predict conditions that could lead to unfavourable settling, but because the calculation is a significant simplification of a complex biological process further validation of the model is required and this could lead to refinement of the approach. Full-scale validation of the predictions will add credibility to the approach and this validation could potentially also provide valuable information about the role of things like channel design, weir design and solids loading on filament proliferation. This risk index approach has the potential to answer questions such as 'Why does one plant bulk and why does another not bulk?' or at the very least identify the issues that lead to settling problems. The approach needs to be validated and extended to include risks related to other potential problems and processes within the WWTP, e.g. membrane fouling potential.

\section{Capital and maintenance costs}

To date, the issue of capital costs has been neglected in the BSM platform. Work in this area is needed because capital expenditures play such a large role in the decision making process (Gillot et al. I999). Simply because a process is more efficient or less susceptible to process upsets does not mean it is the proper course of action if the capital costs to implement the change are prohibitive. A similar argument can be made with respect to operational control strategies if the capital cost to implement the control is more heavily weighted than the benefit being achieved by the control. As currently defined, the BSMs would indicate the benefits from the control, but would not consider the capital cost of implementation nor the maintenance cost or its effect on personnel cost. A capital and maintenance cost index is required, but care will have to be taken to implement it in a jurisdictionally neutral way.

\section{Uncertainty-based evaluation}

In addition to the above traditional metrics, there has been a significant recent research effort in the field of model uncertainty. Uncertainty is a central concept when dealing with biological systems like activated sludge because they are inherently subject to large natural variations (Belia et al. 2009). Traditionally, WWTP process simulators assume constant rather than variable model parameters, and are thus not capable of accounting for the inherent randomness. Even though some of the processes taking place in the UWWS are well known, most of the model parameters are uncertain. Examples of uncertain parameters include the parameters describing the influent COD fractionation, or the parameters describing the effect of temperature or toxic compounds on the kinetics, and all of these have a significant influence on the model predictions. The assessment and presentation of uncertainty is recognised as an important part of the analysis of control strategies for wastewater systems (Beck 1987). The variability and uncertainty in the model results might be captured in a 'robustness' index (Vanrolleghem \& Gillot 2002), i. e. because all mathematical models in use represent simplifications of the treatment processes, it is often of interest to know how reliable or robust the predictions are. 'Will 
small changes in the inputs, parameters or model structure (ASM1-ASM3, different settler models) result in significantly different results?' (Belia et al. 2009). If control is involved, will the operational strategy be able to deal with events appropriately if the models on which it is based are incorrect? In essence, how robust are the model predictions given the unknowns in the model? Consideration of uncertainty during the evaluation of control strategies makes it possible to answer questions such as 'What would happen if there is a change in the influent composition?' and 'What are the expected effects of either temperature changes or toxic spills and will the controller handle them appropriately?' Considering uncertainty when evaluating control strategy performance comes with the advantage that it gives an indication of the robustness of a proposed control strategy, i.e. it will become clear whether a proposed alternative is valid for a narrow range of conditions only or performs well for a broad range of situations (Flores-Alsina et al. 2008).

\section{GHG emissions, carbon footprint and exergy analysis}

Carbon footprinting and GHG emission modelling is becoming important and should, therefore, be incorporated as an additional dimension during the evaluation procedure (e.g. Flores-Alsina et al. 20II; Corominas et al. 2012; Guo et al. 2012). Some work has been dedicated to including the time factor into life cycle assessment (Collet et al. 20II) and could be applied. Research into nitrous oxide emissions from treatment plants is also ongoing and, although the emissions represent a small mass of nitrogen, these emissions have a significant global warming potential. Similarly, methane and carbon dioxide emissions are tied to the relative sustainability of a given process. Finally, besides on-site emissions (direct), off-site emissions (from energy production (indirect) and chemical consumption related emissions (other)) should be included based on a life cycle approach. Assuming that accurate models of these emissions can be developed, then the emissions should be captured by a kind of 'carbon footprint' index that might well include some of the energy cost calculations currently implemented. Exergy, which can encompass information related to energy quality and to resource availability (such as chemicals), could also form an important contribution to such an index (Belhani et al. 2008).

\section{Geographically dependent regulations}

Although the evaluation criteria are meant to be geographically independent, the structure of the indices have always allowed for location-specific criteria to be defined in subsequent analyses. For example, emphasis or weighting terms can be placed on specific performance items depending on location-specific criteria. To formalise this analysis, the inclusion of a legislative module should be considered. Such a tool would allow users to specify regional or national requirements, which in turn may greatly influence what plant configuration and control strategy is the most appropriate for a specific case (e.g. if effluent quality demands are based on 2-hour grab samples or yearly averages, electricity tariffs and costs, sources of energy production available). Clearly such a module would make it impossible to perform objective comparisons of results on a global scale and should therefore not be used if the purpose of the research is general benchmarking. However, its availability would most certainly enhance the use of the benchmark platform to investigate options, solve problems and potentially enhance the overall performance of real WWTPs by allowing for stakeholders in charge of the services to include their local requirements and demands.

\section{CONCLUDING REMARKS}

The BSM systems serve as a very useful and freely available software platform and simulation protocol for research groups all over the world. Whether used for their initially intended purpose of objective benchmarking of control strategies and monitoring methods or as a starting point for other types of investigations is of minor importance. As the IWA Task Group is coming to an end, it is the group's obligation and responsibility to promote potential avenues for future development. A significant number of possible extensions and improvements have been defined in this paper. It is the sincere hope of the Task Group that this will inspire other research groups to continue the development of the BSM systems, thereby allowing them to flourish and remain a state-of-the-art tool for research, development and practical application within the fascinating field of wastewater treatment.

\section{ACKNOWLEDGEMENTS}

A large number of excellent researchers and close friends have contributed to the development of the benchmark systems during the last 15 years and the authors wish to express their sincere gratitude to all of them. Lluís Corominas 
received the 'Juan de la Cierva' scholarship from the Ministry of Spain. Peter Vanrolleghem holds the Canada Research Chair on Water Quality Modelling. Eveline Volcke is a postdoctoral research fellow of the Research Foundation - Flanders (Belgium) (FWO). The support of the International Water Association (IWA) is gratefully acknowledged.

\section{REFERENCES}

Abusam, A., Keesman, K. J., Spanjers, H., van Straten, G. \& Meinema, K. 2002 Evaluation of control strategies using an oxidation ditch benchmark. Water Sci. Technol. 45 (4-5), 151-158.

Alcaraz-Gonzalez, V., Harmand, J., Rapaport, A., Steyer, J.-P., Gonzalez-Alvarez, V. \& Pelayo-Ortiz, C. 2002 Software sensors for highly uncertain WWTPs: a new approach based on interval observers. Water Res. 36 (10), 2515-2524.

Alcaraz-Gonzalez, V., Harmand, J., Rapaport, A., Steyer, J.-P., Gonzalez-Alvarez, V. \& Pelayo-Ortiz, C. 2005 Robust interval-based regulation for anaerobic digestion processes. Water Sci. Technol. 52 (1-2), 449-456.

Alex, J., Ogurek, M. \& Jumar, U. 2005 Formalised model presentation for wastewater systems. In: Proc. 16th IFAC World Congress, Prague, Czech Republic, July 3-8, 2005.

Aquino, S. F. \& Stuckey, D. C. 2002 Characterization of soluble microbial products (SMP) in effluents from anaerobic reactors. Water Sci. Technol. 45 (10), 127-132.

Ashley, R. M., Tait, S. J., Styan, E., Cashman, A., Luck, B., Blanksby, J., Saul, A. \& Sandlands, L. 2007 Sewer system design moving into the 21st century - a UK perspective. Water Sci. Technol. 55 (4), 273-281.

Barker, D. J. \& Stuckey, D. C. 1999 A review of soluble microbial products (SMP) in wastewater treatment systems. Water Res. 33 (14), 3063-3082.

Barret, M., Patureau, D., Latrille, E. \& Carrère, H. 2oıo A threecompartment model for micropollutants sorption in sludge: methodological approach and insights. Water Res. 44 (2), 616-624.

Batstone, D. J., Keller, J., Angelidaki, I., Kalyuzhnyi, S. V., Pavlostathis, S. G., Rozzi, A., Sanders, W. T. M., Siegrist, H. \& Vavilin, V. A. 2002 Anaerobic Digestion Model No.1 (ADM1). IWA Scientific and Technical Report No 13, IWA Publishing, London, UK.

Batstone, D. J., Amerlinck, Y., Ekama, G., Goel, R., Grau, P., Johnson, B., Kaya, I., Steyer, J.-P., Tait, S., Takács, I., Vanrolleghem, P. A., Brouckaert, C. J. \& Volcke, E. 2012 Towards a generalized physicochemical framework. Water Sci. Technol. 66 (6), 1147-1161.

Bauwens, W., Vanrolleghem, P. A. \& Smeets, M. 1996 An evaluation of the efficiency of the combined sewer wastewater treatment system under transient conditions. Water Sci. Technol. 33 (2), 199-208.

Beck, M. B. 1976 Dynamic modelling and control applications in water quality maintenance. Water Res. 10 (7), 575-595.
Beck, M. B. I98I Operational estimation and prediction of nitrification dynamics in the activated sludge process. Water Res. 15 (12), 1313-1330.

Beck, M. B. I987 Water quality modelling: a review of the analysis of uncertainty. Water Resour. Res. 23 (8), 1393-1442.

Belhani, M., Alonso, D. \& Pons, M. N. 2008 The effects of sludge digester biogas recovery on WWTP - ecological impacts and exergetic balance. Int. J. Chem. React. Eng. 6 (1), art. 21, $30 \mathrm{pp}$.

Belia, E., Amerlinck, Y., Benedetti, L., Johnson, B., Sin, G., Vanrolleghem, P. A., Gernaey, K. V., Gillot, S., Neumann, M. B., Rieger, L., Shaw, A. \& Villez, K. 2009 Wastewater treatment modelling: dealing with uncertainties. Water Sci. Technol. 60 (8), 1929-1941.

Benedetti, L. 2006 Probabilistic Design and Upgrade of Wastewater Treatment Plants in the EU Water Framework Directive Context. PhD Thesis, Ghent University, Belgium.

Benedetti, L., Meirlaen, J., Sforzi, F., Facchi, A., Gandolfi, C. \& Vanrolleghem, P. A. 2007 Dynamic integrated water quality modelling: a case study of the Lambro river, northern Italy. Water SA 33 (5), 627-632.

Benedetti, L., Vezzaro, L., Gevaert, V., De Keyser, W., Verdonck, F., De Baets, B., Nopens, I., Vanrolleghem, P. A. \& Mikkelsen, P.-S. 2009a Dynamic transport and fate models for micro-pollutants in integrated urban wastewater systems. In: Proc. 82nd Annual WEF Technical Exhibition and Conference (WEFTEC2009), Orlando, USA, Oct. 10-14, 2009.

Benedetti, L., Prat, P., Nopens, I., Poch, M., Turon, C., De Baets, B. \& Comas, J. 2009b A new rule generation method to develop a decision support system for integrated management at river basin scale. Water Sci. Technol. 60 (8), 2035-2040.

Benedetti, L., De Keyser, W., Nopens, I. \& Vanrolleghem, P. A. 20Io Probabilistic modelling and evaluation of wastewater treatment plant upgrades in a water quality based evaluation context. J. Hydroinformatics 12, 380-395.

Bernard, O., Chachuat, B. \& Steyer, J. P. 2006 State estimation for wastewater treatment processes. In: Wastewater Quality Monitoring and Treatment (P. P. Quevauviller, O. Thomas \& A. Van Der Beken, eds). Wiley, Oxford, UK.

Brehmer, I., Reußner, F., Schütze, M., Muschalla, D. \& Ostrowski, M. 2009 Weiterentwicklung des hessischen Leitfadens zum Erkennen ökologisch kritischer Gewässerbelastungen durch Abwassereinleitungen - Entwicklung einer simulationsgestützten Planungsmethodik (Further development of the Hessian guidelines to determine ecologically critical surface water loads from wastewater discharges - development of a model-based planning methodology). Korrespondenz Abwasser 56 (4), 382-384 (in German).

Borsanyi, P., Benedetti, L., Dirckx, G., De Keyser, W., Muschalla, D., Solvi, A. M., Vandenberghe, V., Weyand, M. \& Vanrolleghem, P. A. 2008 Modelling real-time control options on virtual sewer systems. J. Environ. Eng. Sci. 7 (4), 395-410.

Bürger, R., Diehl, S. \& Nopens, I. 20II A consistent modelling methodology for secondary settling tanks in wastewater treatment. Water Res. 45 (6), 2247-2260. 
Butler, D. \& Schütze, M. 2005 Integrating simulation models with a view to optimal control of urban wastewater systems. Environ. Model. Softw. 20 (4), 415-426.

Collet, P., Hélias, A., Lardon, L. \& Steyer, J.-P. 2on Time and lifecycle assessment: how to take time into account in the inventory step? In: Proc. Life Cycle Management Conference (LCM2011), Berlin, Germany, Aug. 28-31, 2011.

Comas, J., Rodríguez-Roda, I., Gernaey, K. V., Rosen, C., Jeppsson, U. \& Poch, M. 2008 Risk assessment modelling of microbiology-related solids separation problems in activated sludge systems. Environ. Model. Softw. 23 (10-11), 1250-1261.

Copp, J. B. (ed.) 2002 The COST Simulation BenchmarkDescription and Simulator Manual. Office for Official Publications of the European Communities.

Corominas, L., Villez, K., Aguado, D., Rieger, L., Rosen, C. \& Vanrolleghem, P. A. 20II Performance evaluation of fault detection methods for wastewater treatment processes. Biotechnol. Bioeng. 108 (2), 333-334.

Corominas, L., Flores-Alsina, X., Snip, L. \& Vanrolleghem, P. A. 2012 Comparison of different modelling approaches to better understand and minimize greenhouse gas emissions from wastewater treatment plants. Biotechnol. Bioeng. 109 (11), 2854-2863.

Dalmau, J., Comas, J., Rodriguez-Roda, I., Pagilla, K. \& Steyer, J. P. 20Io Model development and simulation for predicting risk of foaming in anaerobic digestion systems. Bioresour. Technol. 101 (12), 4306-4314.

Dapena-Mora, A., Van Hulle, S. W. H., Campos, J. L., Méndez, R., Vanrolleghem, P. A. \& Jetten, M. 2004 Enrichment of anammox biomass from municipal activated sludge: experimental and modelling results. J. Chem. Technol. Biotechnol. 79 (12), 1421-1428.

De Clercq, J., Nopens, I., Defrancq, J. \& Vanrolleghem, P. A. 2008 Extending and calibrating a mechanistic hindered and compression settling model for activated sludge using indepth batch experiments. Water Res. 42 (3), 781-791.

De Keyser, W., Gevaert, V., Verdonck, F., Nopens, I., De Baets, B., Vanrolleghem, P. A., Mikkelsen, P. S. \& Benedetti, L. 2010 Combining multimedia models with integrated urban water system models for micropollutants. Water Sci. Technol. 62 (7), 1614-1622.

Delgadillo, L., Patureau, D., Lardon, L. \& Steyer, J.-P. 20II A new model for bioavailability and cometabolism of micropollutants during anaerobic digestion. Water Res. 45 (15), 4511-4521.

Diehl, S. 2008 The solids-flux theory - confirmation and extension by using partial differential equations. Water Res. 42 (20), 4976-4988.

EC (European Community) 200o Directive 2000/60/EC of the European Parliament and of the Council of 23 October 2000 establishing a framework for Community action in the field of water policy. OJ L327, 1-73.

Fan, J., Vanrolleghem, P. A. \& Lu, S. 2012 A kinetic modeling for carbon metabolism in sequencing batch reactor under multiple aerobic/anoxic conditions. Appl. Microbiol. Biotechnol. 96, 241-252.
Fedorovich, V., Lens, P. \& Kalyuzhny, S. 2003 Extension of Anaerobic Digestion Model No. 1 with processes of sulfate reduction. Appl. Biochem. Biotechnol. 109 (1-3), 33-45.

Flores-Alsina, X., Sin, G., Rodriguez-Roda, I. \& Gernaey, K. V. 2008 Multicriteria evaluation of wastewater treatment plant control strategies under uncertainty. Water Res. 42 (17), 4485-4497.

Flores-Alsina, X., Comas, J., Rodriguez-Roda, I., Gernaey, K. V. \& Rosen, C. 2009 Including the effects of filamentous bulking sludge during the simulation of wastewater treatment plants using a risk assessment model. Water Res. 43 (18), 4527-4538.

Flores-Alsina, X., Corominas, Ll., Snip, L. \& Vanrolleghem, P. A. 20II Including greenhouse gases emissions during benchmarking of wastewater treatment plant control strategies. Water Res. 45 (16), 4700-4710.

Flores-Alsina, X., Gernaey, K. V. \& Jeppsson, U. 2012 Benchmarking biological nutrient removal in wastewater treatment plants: influence of mathematical model assumptions. Water Sci. Technol. 65 (8), 1496-1505.

Ge, H., Zhang, L., Batstone, D. J., Keller, J. \& Yuan, Z. 2013 Impact of iron salt dosage to sewers on downstream anaerobic sludge digesters: Sulfide control and methane production. J. Environ. Eng. (ASCE) 139 (4), 594-601.

Gernaey, K. V. \& Jørgensen, S. B. 2004 Benchmarking combined biological phosphorus and nitrogen removal wastewater treatment processes. Control Eng. Pract. 12 (3), 357-373.

Gernaey, K., Vanrolleghem, P. A. \& Lessard, P. 200I Modelling of a reactive primary clarifier. Water Sci. Technol. 43 (7), 73-82.

Gernaey, K. V., Jeppsson, U., Batstone, D. J. \& Ingildsen, P. 2006 Impact of reactive settler models on simulated WWTP performance. Water Sci. Technol. 53 (1), 159-167.

Gernaey, K. V., Flores-Alsina, X., Rosen, C., Benedetti, L. \& Jeppsson, U. 20II A phenomenological modelling approach for generation of dynamic WWTP influent disturbance scenarios. Environ. Model. Softw. 26, 1255-1267.

Gernaey, K. V., Jeppsson, U., Vanrolleghem, P. A., Copp, J. B. \& Steyer, J.-P. (eds) 2013 Benchmarking of Control Strategies for Wastewater Treatment Plants. IWA Scientific and Technical Report, IWA Publishing, London, UK.

Gillot, S., De Clercq, B., Defour, D., Simoens, F., Gernaey, K. \& Vanrolleghem, P. A. I999 Optimisation of wastewater treatment plant design and operation using simulation and cost analysis. In: Proc. 72nd Annual WEF Conference and Exposition (WEFTEC1999), New Orleans, USA, Oct. 9-13, 1999.

Grau, P., de Gracia, M., Vanrolleghem, P. A. \& Ayesa, E. 2007 A new plant-wide modelling methodology for WWTPs. Water Res. 41 (19), 4357-4372.

Guissassola, A., Sharma, K. R., de Haas, D., Keller, J. \& Yuan, Z. 2009 Development of a model for assessing methane formation in rising main sewers. Water Res. 43 (11), 2874-2884.

Guo, L., Porro, J., Sharma, K. R., Amerlinck, Y., Benedetti, L., Nopens, I., Shaw, A., Van Hulle, S. W. H., Yuan, Z. \& Vanrolleghem, P. A. 2012 Towards a benchmarking tool for minimizing wastewater utility greenhouse gas footprints. Water Sci. Technol. 66 (11), 2483-2495. 
Gustafsson, D. J. I. 20II Nitritation and Denitritation in Sludge Liquor Treatment. PhD Thesis, Lund University, Lund, Sweden.

Harding, T. H., Ikumi, D. S. \& Ekama, G. A. 201 Incorporating phosphorus into plant wide wastewater treatment plant modelling - anaerobic digestion. In: Proc. 8th IWA Symposium on Systems Analysis and Integrated Assessment (Watermatex2011), San Sebastian, Spain, June 20-22, 2011.

Hauduc, H., Rieger, L., Ohtsuki, T., Shaw, A., Takács, I., Winkler, S., Héduit, A., Vanrolleghem, P. A. \& Gillot, S. 201 Activated sludge modelling: development and potential use of a practical applications database. Water Sci. Technol. 63 (10), 2164-2182.

Henze, M., Grady Jr, C. P. L., Gujer, W., Marais, G. V. R. \& Matsuo, T. 1987 Activated Sludge Model No.1. IAWQ Scientific and Technical Report No 1, IWA Publishing, London, UK.

Henze, M., Gujer, W., Mino, T. \& van Loosdrecht, M. C. M. 2000 Activated Sludge Models ASM1, ASM2, ASM2d and ASM3. IWA Scientific and Technical Report No 9, IWA Publishing, London, UK.

Hiatt, W. C. \& Grady, C. P. L. 2008 An updated process model for carbon oxidation, nitrification and denitrification. Water Environ. Res. 80 (11), 2145-2156.

Hvitved-Jacobsen, T., Vollertsen, J. \& Nielsen, P. H. I998 A process and model concept for microbial wastewater transformations in gravity sewers. Water Sci. Technol. 37 (1), 233-241.

Ingildsen, P., Rosen, C., Gernaey, K. V., Nielsen, M. K. \& Jacobsen, B. N. 2006 Modelling and control strategy testing of biological and chemical phosphorus removal at Avedøre WWTP. Water Sci. Technol. 53 (4-5), 105-113.

ITWH 2000 KOSIM 6.2. Anwenderhandbuch (KOSIM 6.2. User Manual). Institut für technisch-wissenschaftliche Hydrologie $\mathrm{GmbH}$, Hannover, Germany (in German).

Jeppsson, U. \& Diehl, S. 1996 An evaluation of a dynamic model of the secondary clarifier. Water Sci. Technol. 34 (5-6), 19-26.

Jeppsson, U., Pons, M.-N., Nopens, I., Alex, J., Copp, J., Gernaey, K. V., Rosen, C., Steyer, J.-P. \& Vanrolleghem, P. A. 2007 Benchmark Simulation Model No 2 - general protocol and exploratory case studies. Water Sci. Technol. 56 (8), 67-78.

Jones, R. M., Dold, P. L., Takács, I., Chapman, K., Wett, B., Murthy, S. \& O'Shaughnessy, M. 2007 Simulation for operation and control of reject water treatment processes. In: Proc. Water Environment Federation 80th Annual Technical Exhibition \& Conference (WEFTEC2007), San Diego, CA, USA, October 13-17, 2007.

Jiang, G., Gutierrez, O., Sharma, K. R. \& Yuan, Z. 2oro Effects of nitrite concentration and exposure time on sulfide and methane production in sewer systems. Water Res. 44 (14), 4241-4251.

Jiang, T., Myngheer, S., De Pauw, D. J. W., Spanjers, H., Nopens, I., Kennedy, M. D., Amy, G. \& Vanrolleghem, P. A. 2008 Modelling the production and degradation of soluble microbial products (SMP) in membrane bioreactors (MBR). Water Res. 42 (20), 4955-4964.
Kampschreur, M. J., Temmink, H., Kleerebezem, R., Jetten, M. S. M. \& van Loosdrecht, M. C. M. 2009 Nitrous oxide emission during wastewater treatment. Water Res. 43 (17), 4093-4103.

Keller, J. \& Yuan, Z. 2002 Combined hydraulic and biological modelling and full-scale validation of SBR processes. Water Sci. Technol. 45 (6), 219-228.

Kinnear, D. J. 2002 Biological Solids Sedimentation: A Model Incorporating Fundamental Settling Parameters. PhD Thesis, Dept. of Civil and Environmental Engineering, University of Utah, Salt Lake City, Utah, USA.

Lardon, L., Punal, A. \& Steyer, J.-P. 2004 On-line diagnosis and uncertainty management using evidence theory experimental illustration to anaerobic digestion processes. J. Proc. Control 14 (7), 747-763.

Lindblom, E., Gernaey, K. V., Henze, M. \& Mikkelsen, P. S. 2006 Integrated modeling of two xenobiotic organic compounds. Water Sci. Technol. 54 (6-7), 213-221.

Lu, S. G., Imai, T., Ukita, M., Sekine, M. \& Higuchi, T. 2002 Modeling prediction of membrane bioreactor process with the concept of soluble microbial product. Water Sci. Technol. 46 (11-12), 63-70.

Maere, T., Verrecht, B., Moerenhout, S., Judd, S. \& Nopens, I. 20 II BSM-MBR: a benchmark simulation model to compare control and operational strategies for membrane bioreactors. Water Res. 45 (6), 2181-2190.

Mampaey, K. E., Beuckels, B., Kampschreur, M. J., Kleerebezem, R., van Loosdrecht, M. C. M. \& Volcke, E. I. P. (in press) Modelling nitrous and nitric oxide emissions by autotrophic ammonium-oxidizing bacteria. Environ. Technol. DOI: 10 . 1080/09593330.2012.758666.

Mhaskar, P. 2006 Robust model predictive control design for faulttolerant control of process systems. Ind. Eng. Chem. Res. 45, 8565-8574.

Ni, B. J., Ruscalleda, M., Pellicer-Nacher, C. \& Smets, B. F. 20 II Modeling nitrous oxide production during biological nitrogen removal via nitrification and denitrification: extensions to the general ASM models. Environ. Sci. Technol. 45, 7768-7776.

Ni, B. J., Yuan, Z., Chandran, K., Vanrolleghem, P. A. \& Murthy, S. 2013 Evaluating four mathematical models for nitrous oxide production by autotrophic ammonia-oxidizing bacteria. Biotechnol. Bioeng. 110 (1), 153-163.

Nopens, I., Batstone, D., Copp, J., Jeppsson, U., Volcke, E. I. P., Alex, J. \& Vanrolleghem, P. A. 2009 An ASM/ADM model interface for enhanced dynamic plant-wide simulation. Water Res. 43 (7), 1913-1923.

Nopens, I., Benedetti, L., Jeppsson, U., Pons, M.-N., Alex, J., Copp, J. B., Gernaey, K. V., Rosen, C., Steyer, J.-P. \& Vanrolleghem, P. A. 2010 Benchmark Simulation Model No 2 - finalisation of plant layout and default control strategy. Water Sci. Technol. 62 (9), 1967-1974.

Oliveira-Esquerre, K. P., Narita, H., Yamato, N., Funamizu, N. \& Watanabe, Y. 2006 Incorporation of the concept of microbial product formation into ASM3 and the modeling of a membrane bioreactor for wastewater treatment. Braz. J. Chem. Eng. 23 (4), 461-471.

Olsson, G. 2012 ICA and me - a subjective review. Water Res. 46 (6), 1585-1624. 
Olsson, G., Nielsen, M., Yuan, Z., Lynggaard-Jensen, A. \& Steyer, J. P. 2005 Instrumentation, Control and Automation in Wastewater Systems. IWA Publishing, London, UK.

Plósz, B. G., Liltved, H. \& Ratnaweera, H. 2009 Climate change impacts on activated sludge wastewater treatment: a case study from Norway. Water Sci. Technol. 60 (2), 533-541.

Plósz, B. G., Leknes, H. \& Thomas, K. V. 20Io Impacts of competitive inhibition, parent compound formation and partitioning behaviour on antibiotic micro-pollutants removal in activated sludge: measurements and modelling. Environ. Sci. Technol. 44 (2), 734-742.

Plósz, B. G., De Clercq, J., Nopens, I., Benedetti, L. \& Vanrolleghem, P. A. 2oIr Shall we upgrade one-dimensional secondary settler models used in WWTP simulators? - an assessment of model structure uncertainty and its propagation. Water Sci. Technol. 63 (8), 1726-1738.

Poinapen, J. \& Ekama, G. A. 20Io Biological sulphate reduction with primary sewage sludge in an upflow anaerobic sludge bed reactor - Part 6: Development of a kinetic model for BSR. Water SA 36 (3), 203-213.

Ráduly, B., Gernaey, K. V., Capodaglio, A. G., Mikkelsen, P. S. \& Henze, M. 2007 Artificial neural networks for rapid WWTP performance evaluation: methodology and case study. Environ. Model. Softw. 22 (8), 1208-1216.

Rauch, W. \& Harremoës, P. 1999 Genetic algorithms in real time control applied to minimize transient pollution from urban wastewater systems. Water Res. 33 (5), 1265-1277.

Rauch, W., Bertrand-Krajewski, J. L., Krebs, P., Mark, O., Schilling, W., Schütze, M. \& Vanrolleghem, P. A. 2002 Deterministic modelling of integrated urban drainage systems. Water Sci. Technol. 45 (3), 81-94.

Reichert, P., Borchardt, D., Henze, M., Rauch, W., Shanahan, P., Somlyody, L. \& Vanrolleghem, P. A. 20or River Water Quality Model No. 1 (RWQM1). IWA Scientific and Technical Report No 12, IWA Publishing, London, UK.

Rieger, L., Alex, J., Winkler, S., Boehler, M., Thomann, M. \& Siegrist, H. 2003 Progress in sensor technology - progress in process control? Part I: Sensor property investigation and classification. Water Sci. Technol. 47 (2), 103-112.

Rittmann, B. E., Bae, W., Namkung, E. \& Lu, C. J. 1987 A critical evaluation of microbial product formation in biological processes. Water Sci. Technol. 19 (3-4), 517-528.

Rosen, C., Jeppsson, U. \& Vanrolleghem, P. A. 2004 Towards a common benchmark for long-term process control and monitoring performance evaluation. Water Sci. Technol. 50 (11), 41-49.

Rosen, C., Aguado, D., Comas, J., Alex, J., Copp, J. B., Gernaey, K. V., Jeppsson, U., Pons, M.-N., Steyer, J.-P. \& Vanrolleghem, P. A. 2008a Inhibition and toxicity modelling with the long term control benchmark model (BSM1_LT) framework. In: Proc. IWA World Water Congress, 2008, Vienna, Austria, Sept. 7-12, 2008.

Rosen, C., Jeppsson, U., Rieger, L. \& Vanrolleghem, P. A. 2008b Adding realism to simulated sensors and actuators. Water Sci. Technol. 57 (3), 337-344.

Rosso, D. \& Stenstrom, M. K. 2006 Economic implications of fine-pore diffuser aging. Water Environ. Res. 78 (8), 810-815.
Schönerklee, M., Peev, M., De Wever, H., Reemtsma, T. \& Weiss, S. 2009 Modelling the degradation of micropollutants in wastewater: parameter estimation and application to pilot (laboratory-scale) MBR data in the case of 2,6-NDSA and BTSA. Water Sci. Technol. 59 (1), 149-157.

Schütze, M., Butler, D. \& Beck, B. I999 Optimisation of control strategies for the urban wastewater system - an integrated approach. Water Sci. Technol. 39 (9), 209-216.

Schütze, M., Reussner, F. \& Alex, J. 20II SWQM - a simple river water quality model for assessment of urban wastewater discharges. In: Proc. 11th International Conference on Urban Drainage (11ICUD), Porto Alegre, Brazil, Sept. 11-15, 2011.

Semadeni-Davies, A. 2004 Urban water management vs. climate change: impacts on cold region waste water inflows. Clim. Change 64 (1-2), 103-126.

Semadeni-Davies, A., Hernebring, C., Svensson, G. \& Gustafsson, L. G. 2008 The impacts of climate change and urbanisation on drainage in Helsingborg, Sweden: combined sewer system. J. Hydrol. 350 (1-2), 100-113.

Sharma, K. R., Yuan, Z. G., de Haas, D., Hamilton, G., Corrie, S. \& Keller, J. 2008 Dynamics and dynamic modelling of $\mathrm{H}(2) \mathrm{S}$ production in sewer systems. Water Res. 42 (10-11), 2527-2538.

Sharma, K. R., Corrie, S. \& Yuan, Z. 20ı2 Integrated modelling of sewer system and wastewater treatment plant for investigating the impacts of chemical dosing in sewers. Water Sci. Technol. 65 (8), 1399-1405.

Siegrist, H., Salzgeber, D., Eugster, J. \& Joss, A. 2008 Anammox brings WWTP closer to energy autarky due to increased biogas production and reduced aeration energy for $\mathrm{N}$ removal. Water Sci. Technol. 57 (3), 383-388.

Sin, G., Kaelin, D., Kampschreur, M. J., Takács, I., Wett, B., Gernaey, K. V., Rieger, L., Siegrist, H. \& van Loosdrecht, M. C. M. 2008 Modelling nitrite in wastewater treatment systems: a discussion of different modelling concepts. Water Sci. Technol. 58 (6), 1155-1171.

Sitzenfrei, R., Fach, S., Kinzel, H. \& Rauch, W. 2010 A multi-layer cellular automata approach for algorithmic generation of virtual case studies: VIBe. Water Sci. Technol. 61 (1), 37-45.

Snip, L. J. P., Boiocchi, R., Flores-Alsina, X., Jeppsson, U. \& Gernaey, K. V. 2013 Expanding activated sludge models with additional processes: A case study based on nitrous oxide production by autotrophic ammonia-oxidizing bacteria. 11th IWA Conference on Instrumentation, Control and Automation (ICA2013), Narbonne, France, 18-20 September 2013 (accepted).

Solvi, A.-M., Benedetti, L., Vandenberghe, V., Gillé, S., Schlosseler, P., Weidenhaupt, A. \& Vanrolleghem, P. A. 2006 Implementation of an integrated model for optimised urban wastewater management in view of better river water quality: a case study. In: Proc. IWA World Water Congress 2006, Beijing, China, Sept. 10-14, 2006.

Spanjers, H., Vanrolleghem, P. A., Nguyen, K., Vanhooren, H. \& Patry, G. G. 1998 Towards a simulation-benchmark for evaluating respirometry-based control strategies. Water Sci. Technol. 37 (12), 219-226. 
Steyer, J. P., Bernard, O., Batstone, D. \& Angelidaki, I. 2006 Lessons learnt from 15 years of ICA in anaerobic digestion processes. Water Sci. Technol. 53 (4-5), 25-33.

Takács, I., Patry, G. G. \& Nolasco, D. 199I A dynamic model of the clarification-thickening process. Water Res. 25 (10), 1263-1271.

Vanhooren, H., Yuan, Z. \& Vanrolleghem, P. A. 2002 Benchmarking nitrogen removal suspended-carrier biofilm systems using dynamic simulation. Water Sci. Technol. 46 (1-2), 327-332.

Vanrolleghem, P. A. \& Gillot, S. 2002 Robustness and economic measures as control benchmark performance criteria. Water Sci. Technol. 45 (4-5), 117-126.

Vanrolleghem, P. A., Benedetti, L. \& Meirlaen, J. 2005a Modelling and real-time control of the integrated urban wastewater system. Environ. Model. Softw. 20 (4), 427-442.

Vanrolleghem, P. A., Rosen, C., Zaher, U., Copp, J., Benedetti, L., Ayesa, E. \& Jeppsson, U. 2005b Continuity-based interfacing of models for wastewater systems described by Petersen matrices. Water Sci. Technol. 52 (1-2), 493-500.

Volcke, E. I. P., Gernaey, K. V., Vrecko, D., Jeppsson, U., van Loosdrecht, M. C. M. \& Vanrolleghem, P. A. 2006a Plant-wide (BSM2) evaluation of reject water treatment with a SHARON-Anammox process. Water Sci. Technol. 54 (8), 93-100.

Volcke, E. I. P., van Loosdrecht, M. C. M. \& Vanrolleghem, P. A. 2006b Continuity-based model interfacing for plant-wide simulation: a general approach. Water Res. 40 (15), 2817-2828.

Watts, R. W., Svoronos, S. A. \& Koopman, B. 1996 Onedimensional modelling of secondary clarifiers using a concentration and feed-velocity dependent dispersion coefficient. Water Res. 30 (9), 2112-2124.

Zumoffen, D. \& Basualdo, M. 2008 Improvements in fault tolerance characteristics for large chemical plants: 1 . Waste water treatment plant with decentralized control. Ind. Eng. Chem. Res. 47, 5464-5481.

First received 14 December 2012; accepted in revised form 5 March 2013 